\title{
„NE HADARJ!”
}

\section{"DO NOT JABBER!"}

\author{
Bokányi Péter \\ irodalomtörténész, a kőszegi Felsőbbfokú Tanulmányok Intézete kutatója \\ peter.bokanyi@iask.hu
}

\begin{abstract}
ÖSSZEFOGLALÁS
Közismert, hogy Hankiss Elemér az irodalomtörténetben is jelentős életművet "tett le az asztalra". Ebben az írásban irodalomelméleti munkáját igyekszem röviden összegezni, emlékeztetve az olvasót, hogy édesapja, Hankiss János személyisége és szaktudása meghatározó hatást gyakorolt Elemér munkájára, amely alapvető jelentőségű a magyar összehasonlító irodalomtörténetben. Először Hankiss János életművét ismertetem, amely előrevetíti Hankiss Elemér műveit, jelentőségüket irodalomtörténetünkben. Írásom jórészt legfontosabb irodalomelméleti - főként a strukturalizmushoz kapcsolódó - munkáira alapozva világítja meg életművének csúcspontjait. Azokat a szinergiákat vizsgálja, amelyek meghatározták a különféle tudományágakban végzett tanári munkáját, és szerves egésszé formálták életművét.
\end{abstract}

\section{ABSTRACT}

The significance of Elemér Hankiss's work is well known in literary history. The aim of this paper is to briefly summarize his work in literary theory as well as to remind the reader of Elemér Hankiss's father, János Hankiss, whose personality and professional life had definitive influence on Elemér Hankiss's work. It is fundamental in the history of comparative literary history of Hungary. The paper begins with evoking János Hankiss's life-work in order to preannounce the continuation: the presentation of the works of Elemér Hankiss and their importance in the field of literary history. The major part of this paper is interpreting the highlights of Hankiss's lifework based on his most significant literary theoretic works - mainly those about structuralism. It examines the synergies which determined the professor's work at several different scientific areas, and also organized the oeuvre of Elemér Hankiss as an integrated whole.

Kulcsszavak: Hankiss, Kőszeg, irodalomtörténet, kérdező ember, tudat, metafora

Keywords: Hankiss, Kőszeg, history of literature, questioning man, consciousness, metaphor

„Kedves testvérem, aki talán megfáradtál s nehezen türöd az egyformaság igáját, te nélkülem is tudod, hogy enyhülést találhatsz abban a különös és csodálatos fürdőben, amit irodalomnak hívsz. Ezt a gyógyfürdőt nem kellett neked megmu- 
tatni: minden tagod ismeri, minden ízed kívánja. Sokat látogatod, talán többször is, mint bevallod magadnak. Az irodalom olyan gyógyvíz, amelyben elvegyül az élet minden hasznos sója: erő, szabadság, szépség, izgalom, varázs, hit, derủ... ki tudná mind elsorolni! Ki tudná felmérni, mit jelent a kis cselédnek a mosogatás mellett az a hazulról hozott dal, amit mély átérzéssel énekel magának; mit jelent a falusi alkonyatban a házba szorult gazdának a kalendáriom írott és rajzolt meséje; mit az iparos-leventének egy egész világot megnyitó regény? Mi lenne az élete, ha valami rettentő varázsló kitisztogatná az irodalmat? Gondolni se jó rá, hiszen az élet egészen az irodalom síkjában adódik az embernek." - írta Hankiss János, Hankiss Elemér édesapja az 1942-ben megjelent, A mi irodalmunk címü kötetének bevezetőjeként. Elegáns és nagyvonalú könyv Hankiss Jánosé: 210 A/5 méretủ oldalon foglalja össze a magyar irodalom történetét. A csekélynek tünő terjedelem magyarázatát ekként adja meg a szerző a zárszóban: „Aki ezt a könyvet hiányzó nevek szempontjából ítélné meg, egészen félreértené szándékunkat. Nem akarhattunk mást, mint kézen fogni a tájékozatlanokat, akik tanácstalanul topognak az irodalom kapui előtt s addig vezetgetni őket, míg soha el nem feledhetően meg nem szokták a maguk lábán való járást” (Hankiss, 1942). Ez, a zárszóból kirajzolódó attitüd Hankiss Elemér életmüvének egészét is jellemezheti. Hankiss, a „kérdező ember” kézen fog és elindít: s aztán adott ponton előzékenyen hátrébb lép, és hagyja, hogy olvasója, az addig „tájékozatlan”, már maga keresse a válaszokat a feltett, elindító kérdésekre.

De nem csak ez a beállítódás az, ami szoros kapcsolatot teremt apa és fiú életművében. Hankiss János (1893-1959), egyik legjelentősebb irodalomtörténészünk pályája sok tekintetben előlegezi Hankiss Elemérét. Genfben és Párizsban végzi egyetemi tanulmányait, 1915-től élete végéig tanít főreáliskolában, egyetemen. Közben közéleti szerepet vállal: 1943-44 közt közoktatási államtitkár a Kállay-kormányban, aztán visszatér a debreceni egyetem katedrájára, ahol 1929 és 1950 közt „,rendes tanár”, 1950-től pedig a Debreceni Egyetemi Könyvtár tisztviselöje és a francia irodalom megbízott előadója. Nevéhez füződik a Helikon címü irodalomelméleti folyóirat alapítása, tizenhat évig szervezője, vezetője volt a debreceni nyári egyetemnek, részt vett a Népmüvelési Kutató Intézet alapításában - élete végén pedig zenetörténettel foglalkozott (föként Liszt Ferenc életével és munkásságával), s neki köszönhető, hogy létrejön a Zenemütár 1958-ban. S alapvetően és meghatározóan irodalmár, aki a magyar és nemzetközi irodalomtudomány kapcsolatainak építésén dolgozik (1931-ben ő szervezi Budapesten az első Nemzetközi Irodalmi Kongresszust), az összehasonlító irodalomtörténet egyik első, meghatározó képviselője Magyarországon.

Vetítsük rá az életútra Hankiss Elemér életművének néhány állomását! Amikor 1993 januárjában a Parlament Kulturális Bizottságának ülésén lemond tévéelnöki posztjáról, a közszereplésről, többek közt ezt mondja: „Hangsúlyozom, hogy nem akarom a Magyar Televízióban elnöki tevékenységemet folytatni. Boldog vagyok, 
hogy újra saját szakmámban dolgozhatok, taníthatok, könyveimet írhatom.” Húsz esztendeig fáradhatatlan résztvevője a kőszegi nyári egyetemnek, részese az ott folyó kutatásoknak, s közhelyszerü emlegetni sokféleségét, a különféle tudományterületek összefonódását életművében. S mindeközben - szíves szóbeli közlése szerint - pályája végén leginkább irodalmárként látta önmagát, ez volt az ő „eredeti szakmája” - ahogy mondta.

„Egy gyerekkori emlék: »Ne hadarj!« Egyetemista koromban az Eötvös Kollégium diákja voltam Budapesten. Szüleim Debrecenben laktak. Édesapámtól minden héten érkezett egy levelezőlap, három utasítás állt rajta, ugyanaz a három szó: »Fésülködj, ne hadarj, húzd ki magad!« Ez máig sem sikerült persze, de ma már tudom, hogy többről volt szó az egyszerủ üzenetnél. Valami ilyesmiről: »Tartsd rendben az életedet, szólj érthető nyelven a világról, a világhoz, őrizd meg emberi méltóságodat, amennyire csak lehet.«" Hankiss Elemér e mondatai 2014. december 15-én, Köszegen hangoztak el $A$ befejezetlen ember címü kötet bemutatóján - ami, azóta tudjuk, Hankiss utolsó nyilvános szereplése volt. Témánk, Hankiss Elemér irodalomelméleti munkássága szempontjából különösen fontosnak tünik a „Ne hadarj!”. Hankiss ugyanis olyan nyelvet teremtett meg - nem is csak irodalmi tárgyú munkáiban -, amely merőben új volt: „,..új értekező nyelveszményt honosított meg a magyar irodalomtudományban. Hankiss stílusa mentes volt a hókuszpókusztól, ködösítéstől és misztifikálástól. Állításait példák sora és a példákból kibontott bizonyítás követte. Írásmódjának elképesztő világossága és kiinduló állításainak egyszerüsége sem fedheti el azt, hogy a könyv nem kevesebbre, mint az irodalom átfogó megismerésére törekedett..." - írja Bezeczky Gábor A népdaltól az abszurd drámáig címü, korszakos jelentőségü Hankiss-kötet kapcsán (Bezeczky, 2015).

Nyelvének újszerüségét $A$ népdaltól az abszurd drámáig kötet egyik tekintélyes, első kritikusa Csetri Lajos is kiemeli: „Hankiss törekvése a természettudományok eredményeinek bevonására az irodalomtudományi vizsgálatokba, terminológiájában is tetten érhető. Feszültség, impulzus, vibrálás, oszcillálás, villanás, ide-oda villódzás stb., a fizikai elektromosságtanból kölcsönzött kifejezések, s az »elektromos« poétika alapszintjére rakódnak rá az irodalmi szöveg bonyolultabb összefüggéseit és a kommunikációs folyamatban elfoglalt helyét jellemezni óhajtó, az információelméletből és a kibernetikából átvett terminus technicusok. [...] az új szakkifejezések csak azt reprezentálják a külsődleges szemlélet számára is, ami az alaposabb vizsgálat során úgyis kiderül: még a hagyományos igazságokat is új megvilágításban, új összefüggésben kapjuk Hankiss tanulmányaiban" (Csetri, 1969). Különösen érdekes a 2015-ben lezárult életmű horizontjából olvasni a közel ötvenesztendős mondatokat. Hankiss Elemér életmüve többek közt abban egyedülálló, ahogy a diszciplínák között, nem egyszer fölött áll, s kapcsol össze magától értetődően látszólag összekapcsolhatatlan dolgokat - tekintsük csak példaként a posztumusz, a Kőszegi Felsőbbfokú Tanulmányok Intézete által 2017- 
ben kiadott Kvantummechanika és az élet értelme címü tanulmányát. (Lásd jelen válogatásban.)

Hankiss Elemér pályájának első, meghatározó korszaka 1965-ben kezdődött: ekkor vette fel az Irodalomtudományi Intézet Irodalomelméleti Osztályára kutatóként Nyírő Lajos, akinek az intézeti munkássága sok tekintetben figyelemre méltó. Nyírő amellett, hogy az Irodalomelméleti Osztályt vezette, egyben az intézet párttitkára is volt: azok közül való, akik e pozíciójukat képesek voltak arra használni, hogy megvédjék a progresszív, új gondolatokat és gondolkodókat. „Nem Nyírő volt az egyetlen, aki olvasta a formalistákat és a strukturalistákat, de ő volt, aki némi intézményes keretet és védelmet tudott biztosítani azoknak, akik rokonszenveztek a strukturalizmussal" (Bezeczky, 2006). Az intézet az Eötvös Kollégium épületében müködött (és müködik), így Hankiss visszakerült a falak közé, ahonnan 1949-ben kényszerủen távoznia kellett. (Az Irodalomtudományi Intézetben jórészt azokat alkalmazták, akiknek valójában egyetemi oktatóként kellett volna müködniük, de politikailag megbízhatatlannak bélyegezték őket, vagyis alkalmatlannak az ifjúság nevelésére.) S idézzük újra Bezeczky Gábort: „Ami munkát Hankiss Elemér az Intézetben néhány év alatt, 1965 és 1972 között elvégzett, a magyar irodalomtudomány történetének legszebb, legfontosabb, legérdekesebb fejezetei közé tartozik. Ügyet sem vetett a korabeli magyar irodalomtörténeti lapokban és könyvekben tárgyalt témák legtöbbjére. Egyebek mellett nem volt mondandója sem a realizmusról, sem a szocialista realizmusról, nem szólt hozzá a kritika-vitához, nem sokat törődött Lukács György elgondolásaival, talán sehol sem említi, mindenesetre sehol sem tárgyalja a Sőtér István föszerkesztésében megjelent akadémiai irodalomtörténetet. Hosszan lehetne sorolni, mi minden hagyta hidegen. Ezzel szemben úgy hivatkozott a kortárs nyugati irodalomelméleti szakirodalomra (ekkoriban a hajdani orosz formalizmust is nyugati kiadványokból lehetett ismerni), mintha ez nem föbenjáró bün, hanem a világ legtermészetesebb dolga lett volna. Érzékeny ponton találta el a hazai - marxista és hagyományos - irodalomtudományt, melynek ezáltal azonnal megmutatkozott az avíttsága, bezápultsága, tájékozatlansága. Amikor 1971-ben megjelent Strukturalizmus címü kétkötetes válogatása, bár volt némi acsarkodás, de már senki nem merészelte vitatni az irodalomelméleti tájékozottság követelményét. Ezt a hatalmas fordulatot minden kétséget kizáróan ő vitte végbe. Voltak társai, tagadhatatlan, de az áttörés neki köszönhetö" (Bezeczky, 2015). Ezen áttörés lényege, hogy Hankiss Elemér és munkatársainak tevékenysége a strukturalizmus jegyében ráébresztette a magyar irodalomtudományt, hogy hosszú ideje Hamupipőke-álmot alszik: évtizedek szálltak el fölöttük úgy, hogy a marxista irodalomtudomány dogmatizmusa okán észre sem vették, hogy miféle új, más irodalomelméleti iskolák, gondolkozási formák léteznek a nemzetközi irodalomtudományban. Vagyis Hankiss Elemér irodalomtudományi tevékenysége bőven túlmutat önnön kétségtelen értékein: egyben ablakként nyitott rá a nemzetközi 
tendenciákra. Ezt a megállapítást Csetri Lajos korábban idézett cikke is megerősíti: A népdaltól az abszurd drámáig kötet Irodalomtörténeti Közlemények-béli recenziójának bevezetéseként arról beszél, hogy mennyire üdvös, hogy e könyv valamennyi tanulmánya ,a magyar irodalomtudományban eddig szokatlan, s ezért különösen figyelemre méltó módszereket igyekszik alkalmazni költői alkotások vizsgálatára. Ezek a módszerek ma már úgyszólván valamennyi nagyobb európai nemzet irodalomtudományában meghonosodtak, nagy hagyományai vannak néhány környező nép, pl. a csehszlovák és a lengyel tudományosságában, a mi tudományunkban azonban úgyszólván előzmény nélküliek, s ezért az elmúlt években létjogosultságuk elméleti igazolása, valamint a standard külföldi eredmények ismertetése volt soron" (Csetri, 1969).

A strukturalizmus hazai története 1968-ban, a Helikon 1968/1 számával kezdődik. A lapszám alapszövegeket közölt, többek közt Roman Ingarden, Jurij Lotman, Roland Barthes, Roman Jakobson, Claude Lévi-Strauss munkáit, viszont valódi diskurzussá a téma csak az évtized végére teljesedett, elsősorban Hankiss Elemér munkái kapcsán. 1969-ben jelent meg Hankiss e korszakának kétségkívül legkiemelkedőbb produktuma, a már többször említett $A$ népdaltól az abszurd drámáig címü tanulmánykötet. A könyv nyolc tanulmánya közül jó néhány legendássá lett: például a vers intenzitásának mérhetőségén töprengő József Attila komplex képei, a címadó A népdaltól az abszurd drámáig, a korabeli slágerszövegek kapcsán keletkezett „,Sorrentói narancsfák közt...” című dolgozatig mindegyik a magyar irodalomelméleti gondolkozás alapmunkája. Hankiss tanulmányainak újszerüsége, mássága a fentebb említett új terminológia mellett abban állt, ahogy magától értetődően lépett túl a marxista irodalomtudomány kérdésfelvetésein, problémáin: ahogy Bezeczky Gábor fentebb idézett szövege jelzi, nem vitatkozott, nem konfrontálódott, egyszerüen máshogy és másról beszélt. Az általa szerkesztett, 1971-es megjelenésủ Strukturalizmus bevezetőjében sorra veszi mindazt, ami az ő irodalomelméleti gondolkozását vezérli - s ami, ki nem mondva, szemben áll a marxista irodalomtudomány gondolkozási rendszerével. A strukturalista - mondja - a tovább nem redukálható elemi részek egymáshoz való viszonyát kutatja, a belső összefüggések dinamikáját, ahogy az elemi egységek struktúrává szerveződve jutnak/juttatnak el valamiféle hatásig (szellemes hasonlata szerint a gótikus katedrálist sem az egyes kövek, hanem azok egymáshoz való viszonya, az egésszé szerveződő struktúra teszi azzá, ami). A strukturalistát nem a rendszer létrejötte, hanem maga a rendszer érdekli, annak müködése és részeinek egymáshoz való viszonya, legyen az „társadalmi rendszer, egy nyelv, egy élő sejt, egy gyár, egy kultúra, egy müalkotás”, törvényszerűségek érdeklik, és nem a jelenségek. S módszerként a formalizálás, hogy a képletekbe, modellekbe rögzítés megteremtse a lehetőségét az egyes, addig össze nem hasonlítható (tudomány)területek összevetésének, a diszciplínák fölött/mögött álló törvényszerüségek kutatásának. „A tudományágak közötti, úgynevezett 
interdiszciplináris szemlélet [...] csaknem állandó velejárója a strukturalista kutatásnak" (Hankiss, 1971).

Az immár lezárult életmü horizontjából különösen izgalmasak ezek a mondatok. Mint fentebb említettük, szinte közhelyszerü Hankiss Elemér sokféleségéről beszélni: irodalmár, szociológus, filozófus stb. Fentiek értelmében nagyot hibázunk, ha azt vizsgáljuk, mely tudományterületen mit ért el Hankiss: elemeket nézünk s nem azok összefüggéseit. Hankiss Elemér teljes életmüvében strukturalista volt, s, ahogy idéztük őt, ennek velejárója az interdiszciplináris szemlélet. Vagyis Hankiss nem „8van”, ahogy a 80. születésnapjára kiadott kötet szellemes alcíme mondja (Miszlivetz, 2008), nincs irodalmár, filozófus és más Hankiss Elemér: egy van, a strukturalista, akit a rendszer müködése érdekel, legyen a rendszer társadalmi, filozófiai vagy müalkotásbéli - vagy akár az Egész müködésének rendszere - amiről utolsó kötete, A befejezetlen ember beszél.

Ahogy mondtuk, Hankiss nem vitatkozik a marxista irodalomtudománnyal. Ugyanakkor minden állítása kétségbe vonja azt, anélkül, hogy ő konfrontálódni akarna. Hankiss nem lázadó és forradalmár a magyarországi irodalomelméletben. Mást gondol, és máshogy. És mutat a meglévő mellett valamit, hogy mi is lehetne.

A marxista irodalomtudomány csírái közel azonos időben születtek meg, mint a történeti-filológiai elméleté. Marx az 1840-es évektől többször foglalkozik a művészet fogalmával, az irodalom társadalmi szerepével. Olyan társadalomfilozófiát és társadalmi gyakorlati modellt alakított ki, amely elkerülhetetlenül integrálta az irodalmat, mégpedig mind filozófiai értelemben azzal, hogy definiálta a müvészet létmódját, mind gyakorlati szempontból azzal, hogy a megértést, megértetést, sőt az önmegértés társas problémáját fontos politikai-gyakorlati kérdéssé tette. A marxizmus klasszikusai esetében ez az általános filozófiai keret és társadalompolitikai következmény messze fontosabb, mint a közvetlen irodalomtudományi gondolatok sora. Az általános elméleti alap talán három közismert jellemzővel, tézissel szemléltethető. Az első a lét és tudat viszonyának elve, mely a legáltalánosabb ontológiai alapelv. Eszerint a létezésnek többféle rétege van, amelyek közül a tárgyiasan fennálló, a természeti meghatározza a tudat állapotait, elsődleges azzal szemben. A szellemi produktumok, köztük az irodalmi múvek is, ennek a megalapozó társadalmi létnek a visszatükröződései, és megértésük úgy történhet meg, hogy felfedezzük genezisük társadalmi titkait. A műalkotások egy hosszú következménysor végén állnak, a termelési erők és a nyomukban megformálódó termelési viszonyok következményei. A nem vulgáris marxizmusban az alap és felépítmény, a termelési erők és az irodalom közötti viszony nem ok-okozati, hanem feltétel-következmény (Lukács kifejezésével: „ha, akkor”) típusú. Az ortodox marxizmus újfajta genetikus elméletet alakít ki, olyan „általános személyeket" fedez fel, akikkel helyettesíteni tudja a történeti-filológiai módszerben kulcsszerepet játszó szerző személyét. Eszerint az irodalom az osztálytudat kife- 
jeződése, vagy később, a „nembeli lényeg” artikulációja. A műalkotás értelmezése az osztálytudat vagy a nembeli öntudat releváns részének megragadása. Ezért a marxizmus ugyan fenntartja a szerző-mü reláció jelentőségét, de az értelemépítés központi elemévé azt a kérdést teszi, hogy a műalkotás milyen társadalmi érdekeket, milyen osztályokat képvisel, adott esetben akár szerzőjének szándéka ellenére is. A müalkotás értelme tehát nem a szerzői szándékkal egyenlö, hiszen a szerző szokásosan áldozata a számára kikerülhetetlen „hamis tudatnak”, hanem az a társadalmi értelem jelenik meg benne, amelyet az adott közösség, osztály önmagáról, környezetéről akkor és ott, ténylegesen vagy inkább csak elvileg, meg tudott ragadni. Így lett a klasszikus marxista irodalomelmélet alapfogalma a viszszatükrözés.

Ezzel szemben Hankiss deklarálja idézett cikkében: csak a mủ a fontos, a benne rejlő erővonalak, illetve az erővonalak mentén kirajzolódó struktúra. De nem ez az egyetlen kijelentése, aminek révén közvetve tagadja a marxista irodalomtudomány kizárólagosságát. A strukturalizmus egyik lényeges elemeként említi több helyütt is, hogy az törekszik az egyszerü, lineáris ok-okozati összefüggések helyett bonyolultabb, többoldalú összefüggésrendszereket vizsgálni. Deklarálja - szemben a marxista irodalomtudománnyal - hogy a strukturalistát nem a rendszer létrejötte, illetve a létrejöttét előidéző ok-okozati kapcsolatok, hanem maga a rendszer érdekli: a müalkotás a maga belső viszonyrendszereivel, az ezekből adódó hatásmechanizmusokkal - azokkal a belső törvényekkel, amelyek a müalkotást azzá teszik, ami. Vagyis ,általában inkább a törvényszerüségek érdeklik, mint a jelenségek". Legendássá lett tanulmányai (például a metafora hatásáról vagy a Megy a juhász a szamáron címü Petőfi-versről) ezt a szemléletet tükröztetik: a tudósét, akit nem az érdekel, mi ez, és hogyan lett ilyenné, hanem sokkal inkább, hogy mi az, ami megtartja annak, ami: mủalkotásnak, ami él és eleven.

Ez a szemléletmód - ahogy fentebb is mondtuk - nem reked meg az irodalomtudomány keretein belül. Onnan indul Hankissnál, de, ahogy a strukturalizmus alapmüveiből is látszik (lásd a fentebb említett Helikon-szám), a strukturalizmus mint gondolkozásmód bőven túlmutat egyetlen diszciplína keretein. Hankiss idézett szövegében úgy a természettudományok, mint a társadalomtudomány helyet kap: mindkettő úgy, mint előlegezője a másfajta irodalomelméleti gondolkozásnak. A természettudományokkal szemben - írja - alapvető elvárás már az újkor elejétől, hogy a jelenségeket rendszerként vizsgálják, a társadalomtudományokkal szemben ezek az elvárások sokáig nem müködtek. Ezért véli meghatározónak a közgazdaságtan tudományának megjelenését: az első olyan társadalomtudomány-terület, amelyben kialakultak a természettudomány egzaktságára emlékeztető módszerek, az első olyan, amely rendszerként tekint gazdaságra, társadalomra, kultúrára, müvészetre. Tehát $a b$ ovo „interdiszciplináris”, mivel a változó - $\mathrm{s}$ a 20. században különösen gyorsan változó - rendszerek felvetette kérdésekre csak 
így lehet válaszokat keresni: magát a rendszert s az azt mozgató törvényszerüségeket vizsgálva.

Hankiss Elemérről szólván az életmű lezárultával szokás „korszakokat” emlegetni. Eszerint lenne az irodalomtudós, a szociológus, a filozófus stb.; meggyőződésünk, egyazon gondolatsor folytatódott a pálya kezdetétől annak végéig: egy rendszerelvü, a rendszer törvényszerüségeire koncentráló, azokat felmérni és megérteni akaró tudós gondolatsora. Nyilván lehet(ne) számszerüsíteni az egyes tudományterületeken végzett munkáit, publikációinak, szerkesztéseinek mennyiségét, $\mathrm{s}$ beszélni arról, „mit tett le az asztalra” az egyes diszciplinákban - csakhogy ez épp a hankissi életmü egészének mond ellent. Hankiss Elemér konzekvensen vitt végig egy gondolatsort, mint említettük: életmüvét vizsgálva nem az egyes területek, hanem maga az egész az, ami számít, az a gondolatsor, amely történetesen az irodalomtudományból indult, s folytatódott más tudományterületeken. Vannak persze, nagy pillanatok: A népdaltól az abszurd drámáig, a Diagnózisok, Az emberi kaland stb., de sokkal fontosabbak az ezeket összekapcsoló erővonalak, azok a szinergiák, amelyek mind ugyanonnan származnak: a tudományágak feletti, az egészre és annak müködésére koncentráló gondolkozásból.

\section{IRODALOM}

Bezeczky G. (2006): A strukturalizmus Magyarországon. 2000, 4, 64-76. http://ketezer. hu/2006/04/a-strukturalizmus-magyarorszagon/

Bezeczky G. (2015): Hankiss Elemér (1928-2015). Literatura, XLI, 1, 3-6. http://www.balassikiado.hu/BB/NET/LITERATURA/Liter2015_1.pdf

Csetri L. (1969): Hankiss Elemér: A népdaltól az abszurd drámáig. Irodalomtörténeti Közlemények, LXXIII, 6, 742-743. http://epa.oszk.hu/00000/00001/00264/pdf/00264.pdf

Hankiss E. (1971): Strukturalizmus I-II. Európa, Budapest

Hankiss J. (1942): A mi irodalmunk. Budapest: Királyi Magyar Egyetemi Nyomda

Hankiss J. (1994): Orvosi Hiszekegy. Mezöberényi Hírmondó. 1, 11. http://www.mezobereny.hu/ adattar/hirmondo/561_0_1_199401-239887.pdf

Miszlivetz F. (szerk.) (2008): Hankiss 8van? Találjuk ki...! Tanulmányok Hankiss Elemér tiszteletére. Szombathely: Savaria University Press 